\title{
Spatial Coherence of Water Vapor and Rainfall over the Indian Subcontinent during Different Monsoon Seasons ${ }^{\mathscr{O}}$
}

\author{
BASIVI RADHAKRISHNA AND T. NARAYANA RAO \\ National Atmospheric Research Laboratory, Department of Space, Government of India, Gadanki, Andhra Pradesh, India \\ K. SAIKRANTHI \\ Indian Institute of Science Education and Research Tirupati, Tirupati, Andhra Pradesh, India
}

(Manuscript received 26 April 2018, in final form 19 November 2018)

\begin{abstract}
Spatial coherency in atmospheric water vapor and rainfall and their association have been studied over the Indian subcontinent utilizing high spatiotemporal resolution data. Total column water vapor (TCWV) values derived from the Indian National Satellite (INSAT) system series (INSAT-3D) are first evaluated against data from an International GNSS Service (IGS) GPS receiver at Bangalore and the Global Precipitation Measurement Microwave Imager (GMI). The bias, correlation coefficient, and RMSE of TCWV between INSAT-3D and GMI show that, except for the south Bay of Bengal, the datasets compare well. The seasonal mean TCWV shows large values with lower standard deviation during the southwest monsoon (SWM) than in the northeast monsoon (NEM). Different temporal scales that contribute to the TCWV variance at a given point are quantified, and the variability due to 30-60-day oscillations is found to be dominant during both the monsoon seasons. TCWV and rainfall show good correspondence over the whole Indian subcontinent during both monsoon seasons except over the Arabian Sea and southern Myanmar regions, where large TCWV values show less rainfall during the SWM. On the whole, the spatial homogeneity and intergrid correlations in TCWV and rainfall are higher in NEM than in SWM. The decorrelation distance $d_{0}$ for TCWV is found to be 10 times larger than that for rainfall, indicating that the rainfall homogeneity is generally limited to smaller areas. The large $d_{0}$ values of TCWV are mainly due to the occurrence of source and sink processes at large spatial scales over those regions.
\end{abstract}

\section{Introduction}

Water vapor is one of the prime elements of the atmosphere, which alters atmospheric thermodynamics, the radiation budget, and also the hydrological cycle. As known to the common public, tending to humid is sustained intense rainfall. The total column water vapor (TCWV) and precipitation are well associated in the tropics (Bretherton et al. 2004; Peters and Neelin 2006; Neelin et al. 2009; Holloway and Neelin 2009; Muller et al. 2009; Ahmed and Schumacher 2015). TOGA COARE experimental data and the subsequent modeling studies showed that the decrease

\footnotetext{
Supplemental information related to this paper is available at the Journals Online website: https://doi.org/10.1175/JHM-D-180069.s1.

Corresponding author: Dr. Basivi Radhakrishna, rakibasivi@ gmail.com
}

in midtropospheric water vapor prevents deep convection over the western Pacific warm pool (Brown and Zhang 1997; Parsons et al. 2000; Redelsperger et al. 2002; Ridout 2002). When atmospheric vertical wind shear is weak, the role of water vapor in the lower free troposphere is much more critical for the generation of deep convection (Tompkins 2001). Further, Derbyshire et al. (2004) confirmed the sensitivity of moist convection to lower-free-tropospheric humidity using cloud-resolving model (CRM) and single-column model simulations. Intercomparisons of global climate model (GCM) simulations revealed that the models reproduce the most realistic Madden-Julian oscillation when they capture a transition from low-level moistening for light precipitation to upper-level moistening for heavy precipitation (Klingaman et al. 2015). Hence, understanding of spatiotemporal variability of water vapor and its relation with rainfall (Bretherton et al. 2004; Radhakrishna et al. 2015; Kuo et al. 2017) is essential to study weather and climate processes (Kay and Box 2000) and also 
large-scale atmospheric processes like monsoon variability (Singh et al. 2000, 2004; Prasad et al. 2007).

Observational and modeling approaches across various temporal and spatial scales clearly reveal the connections between free-tropospheric water vapor and deep convection because turbulent entrainment of dry versus moist air has different impacts on buoyancy of convective plumes (Jensen and Del Genio 2006; Holloway and Neelin 2009, 2010; Lintner et al. 2011; Schiro et al. 2016). These studies concluded that total column water vapor (TCWV) can be used as a proxy for environmental impacts on conditional instability. At convective time scales, satellite observations showed a positive correlation between TCWV and precipitation. This relationship shows a sharp increase in precipitation rate when TCWV exceeds a certain threshold value (Bretherton et al. 2004; Peters and Neelin 2006; Neelin et al. 2009). However, the satellite data used in these studies are at twice-daily or coarser temporal resolution. Also, they do not attempt to analyze temporal relationships between TCWV and precipitation. Using radiosonde and rain gauge data, Holloway and Neelin (2009) showed that high TCWV corresponds to high precipitation at little or no lag. They also showed that the boundary layer and lower-tropospheric water vapor can lead precipitation by an hour or two whereas middle- and upper-tropospheric water vapor tends to lag precipitation by the same amount of time, corroborating the study by Sobel et al. (2004). Using rawinsonde and satellite data, Sherwood and Wahrlich (1999) showed that TCWV is high within $3 \mathrm{~h}$ of convective initiation and then decreases during and after convection, but again they used fairly coarse temporal resolution. With high time resolution radar and ground-based GPS receiver network data over the continental United States (CONUS), Radhakrishna et al. (2015) further confirmed that that TCWV peaks $3 \mathrm{~h}$ before the meso- $\alpha$-scale convective onset and then changes differently during and after convection at diverse geographical regions.

Utilizing the Nauru station microwave radiometer and optical rain gauge 5-min averaged data, Neelin et al. (2008) and Holloway and Neelin (2010) showed that TCWV is a relatively slowly changing predictor when compared to column liquid water and precipitation. The TCWV variability is likely related to that of lowertropospheric moisture (Holloway and Neelin 2009), which in turn increases the buoyancy of entraining plumes, enhancing the chance of deep convection. The aforementioned studies showed the link between TCWV and precipitation at different temporal scales, but what is less known is the spatiotemporal coherence in water vapor and precipitation over different geographical regions at different temporal scales.
The predictability of TCWV and precipitation in time and space has a number of potential implications such as mechanisms of mesoscale organization and the extent to which TCWV can be used as a forecaster of future precipitation (e.g., in stochastic parameterization).

The present study mainly focuses on the Indian subcontinent because the economy of an agro-rain country like India heavily depends on the monsoonal rain, and as a whole it receives most of the annual rainfall during the southwest monsoon (SWM) season [June-September (JJAS)], except for southeast peninsular India, which receives $\sim 45 \%$ of its annual rainfall during the northeast monsoon (NEM) season [October-December (OND)]. Using rain gauge network data over the Gadanki region, Sunilkumar et al. (2016) studied the small-scale spatial homogeneity in rainfall. However, no studies exist that deal with the spatiotemporal coherence in TCWV and rainfall over different geographical regions of the Indian subcontinent. This is due to the lack of simultaneous measurements of TCWV and rainfall at high spatiotemporal scales. The meteorological satellite of the Indian National Satellite (INSAT) system series (INSAT-3D) provides high spatiotemporal resolution of TCWV data from August 2013 onward over the Indian subcontinent. Knowing the importance of TCWV and precipitation relations for the societal benefits, the present study aims first to validate the INSAT-3D-derived TCWV data at different temporal scales. Then, using the simultaneous rainfall data from Integrated Multisatellite Retrievals for Global Precipitation Measurement (IMERG), the spatiotemporal coherency of TCWV and rainfall and their association has been studied over different geographical regions of India and its adjoining seas during the two monsoon seasons, that is, SWM and NEM. In particular, the paper aims to study 1) the water vapor variability at different temporal scales and their contribution to total variance of water vapor and 2) the water vaporprecipitation relations in terms of their spatial coherence (or decorrelation distance) and in light of their sources and sinks. This study has been carried out in different climatic zones of India and different monsoon seasons.

\section{Data}

The INSAT system is a series of multipurpose geostationary satellites launched by the Indian Space Research Organization (ISRO) to cater to the telecommunications, broadcasting, meteorology, exploration, and rescue needs of India. The meteorological satellite INSAT-3D is placed at $82^{\circ} \mathrm{E}$ in a geosynchronous orbit and carries a multispectral imager (radiometer) capable of generating images of Earth in six wavelength bands, namely, visible $(0.55-0.75 \mu \mathrm{m})$, shortwave infrared $(1.55-1.7 \mu \mathrm{m})$, middle 
TABLE 1. INSAT-3D sounder infrared channel description.

\begin{tabular}{|c|c|c|c|c|}
\hline Channel No. & Spectral band & Wavelength $(\mu \mathrm{m})$ & Principal absorbing gas & Purpose \\
\hline 1 & LWIR-1 & 14.71 & $\mathrm{CO}_{2}$ & Stratospheric temperature \\
\hline 2 & LWIR-2 & 14.37 & $\mathrm{CO}_{2}$ & Tropopause temperature \\
\hline 3 & LWIR-3 & 14.08 & $\mathrm{CO}_{2}$ & Upper-level temperature \\
\hline 4 & LWIR-4 & 13.64 & $\mathrm{CO}_{2}$ & Midlevel temperature \\
\hline 5 & LWIR-5 & 13.37 & $\mathrm{CO}_{2}$ & Low-level temperature \\
\hline 6 & LWIR-6 & 12.66 & $\mathrm{H}_{2} \mathrm{O}$ & Total precipitable water \\
\hline 7 & LWIR-7 & 12.02 & $\mathrm{H}_{2} \mathrm{O}$ & Surface temperature and moisture \\
\hline 8 & MWIR-1 & 11.03 & Window & Surface temperature \\
\hline 9 & MWIR-2 & 9.71 & Ozone & Total ozone \\
\hline 10 & MWIR-3 & 7.43 & $\mathrm{H}_{2} \mathrm{O}$ & Low-level moisture \\
\hline 11 & MWIR-4 & 7.02 & $\mathrm{H}_{2} \mathrm{O}$ & Midlevel moisture \\
\hline 12 & MWIR-5 & 6.51 & $\mathrm{H}_{2} \mathrm{O}$ & Upper-level moisture \\
\hline 13 & SWIR-1 & 4.57 & $\mathrm{~N}_{2} \mathrm{O}$ & Low-level temperature \\
\hline 14 & SWIR-2 & 4.52 & $\mathrm{~N}_{2} \mathrm{O}$ & Midlevel temperature \\
\hline 15 & SWIR-3 & 4.45 & $\mathrm{CO}_{2}$ & Upper-level temperature \\
\hline 16 & SWIR-4 & 4.13 & $\mathrm{CO}_{2}$ & Boundary layer temperature \\
\hline 17 & SWIR-5 & 3.98 & Window & Surface temperature \\
\hline 18 & SWIR-6 & 3.74 & Window & Surface temperature and moisture \\
\hline
\end{tabular}

infrared $(3.8-4 \mu \mathrm{m})$, water vapor infrared $(6.5-7.1 \mu \mathrm{m})$, and two bands in thermal infrared regions (TIR-1 at $10.3-11.3 \mu \mathrm{m}$ and TIR-2 at $11.5-12.5 \mu \mathrm{m})$. The imager generates images of the Earth disk from a geostationary altitude of $36000 \mathrm{~km}$ every $26 \mathrm{~min}$. The sounder on board the INSAT-3D possesses 18 infrared channels distributed in longwave (LWIR), medium-wave (MWIR), and shortwave (SWIR) bands and one visible channel to provide a synoptic view of the clouds and Earth. The selected frequencies and their purpose are described in Table 1. The spatial resolution of all channels at Earth's surface is $10 \mathrm{~km} \times 10 \mathrm{~km}$. INSAT-3D measurements have been converted into brightness temperature using lookup tables provided with level-1 data (Katti et al. 2006). Using the brightness temperature dataset, the cloud mask is generated following the algorithm of Ackerman et al. (1998). To avoid the scattering effects in the radiative transfer equation, this cloud mask is used to identify the clear-sky areas, and water vapor profiles are retrieved in those regions. The retrieved water vapor profiles are integrated to get the TCWV. The algorithms used in the INSAT-3D retrievals are employed from physical and regression-based retrievals (Ma et al. 1999; Li et al. 2000) adapted from the operational High Resolution Infrared Radiation Sounder (HIRS) and Geostationary Operational Environmental Satellites (GOES) algorithms. Hourly values of TCWV retrieved from the sounder during 2014-16 are utilized in the present study. To retain the uniform grid spacing, the INSAT-3D data are regridded to $0.1^{\circ} \times 0.1^{\circ}$ spatial resolution without applying any spatial interpolation.

Realizing the significance of atmospheric water vapor in the scenario of freshwater management and climate change, people started measuring it continuously. The instruments that measure atmospheric TCWV and their limitations are well documented in Radhakrishna et al. (2015). Ground-based GPS receivers measure TCWV with high accuracy ( $<1 \mathrm{~mm}$; Braun and Van Hove 2005) in all weather conditions. Comparisons of GPS-derived TCWV with radiosondes and microwave radiometers show a high level of agreement between them with a trivial under estimation by GPS (Dumont and Zabransky 2001; Brown et al. 2002; Dai et al. 2002). Thus, to validate the TCWV data from INSAT-3D, data from a ground-based GPS receiver installed at the Indian Institute of Science $\left(13.0212^{\circ} \mathrm{N}, 77.5704^{\circ} \mathrm{E}\right)$, Bangalore (site name IISC), are considered. This dataset is obtained from the SuomiNet-Global Map data (http://www.suominet.ucar.edu/indexGlobal.html). GPS data were analyzed at UCAR using the Bernese software, version 5.0 (Dach et al. 2007), via an ionosphere-free double-difference network strategy. Also, we have used Global Precipitation Measurement (GPM) Microwave Imager (GMI)-derived TCWV to validate the INSAT-3D-retrieved TCWV. The GMI channels are the same as Tropical Rainfall Measuring Mission (TRMM) Microwave Imager (TMI) with additional channels at 166 and $183 \mathrm{GHz}$. These channels bring more information on cloud water, frozen hydrometeors, and the atmospheric moisture profile (Gong and $\mathrm{Wu} 2017$ ).

The rainfall information is obtained from the IMERG version 5 (research/final run) data with a spatiotemporal resolution of $0.1^{\circ} / 30 \mathrm{~min}$ during 2014-16. The technical details of the IMERG rainfall data are found in Huffman et al. (2017). To augment the results, interpolated 3D gridded (Houze et al. 2015) TRMM 

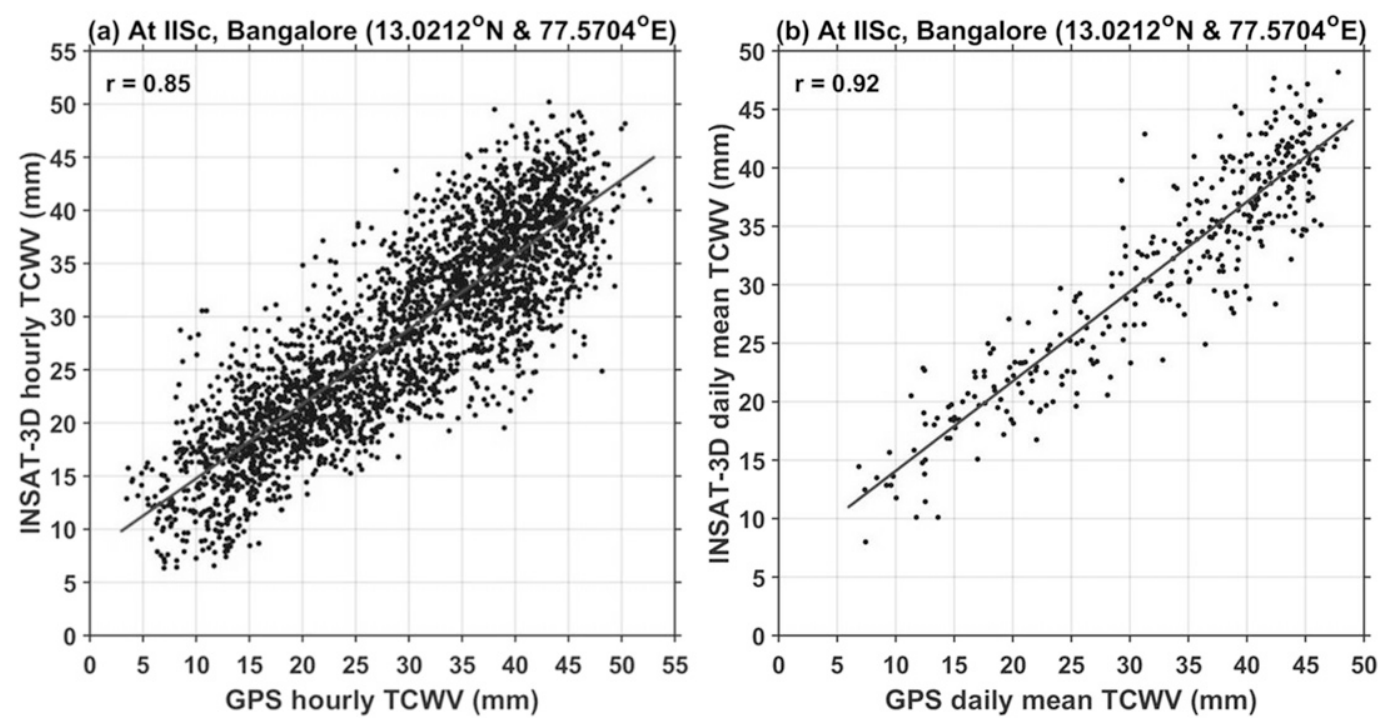

FIG. 1. Comparison of (a) hourly and (b) daily mean TCWV (mm) during both SWM and NEM seasons obtained from a ground-based GPS receiver installed at IISC and INSAT-3D at that location for the period 2014-16. The overlaid lines indicate the linear fit to the data, and $r$ represents the Pearson correlation coefficient value.

Precipitation Radar (PR) version 7 delineated convective, stratiform, and shallow rain dataset have been used. Apart from these datasets, European Centre for Medium Range Weather Forecasting (ECMWF) interim reanalysis (ERA-Interim) winds at the 850 -hPa level are also used.

\section{Results}

The quality of the INSAT-3D-derived TCWV dataset is checked in two ways. First, ground-based GPSreceiver-derived TCWV values have been used to validate the INSAT-3D data. To do this, the TCWV values are considered from the site IISC via SuomiNet global archival data and the INSAT-3D data within a $5-\mathrm{km}$ radius from the IISC site location $\left(13.0212^{\circ} \mathrm{N}, 77.5704^{\circ} \mathrm{E}\right)$. The comparisons of hourly TCWV and daily mean TCWV between GPS and INSAT-3D at the IISC site are shown in Fig. 1. As INSAT-3D TCWV retrievals are limited to rain-free conditions, the daily mean TCWV values are computed utilizing the data only when concurrent measurements are available. The comparisons shown in Fig. 1 illustrate a good agreement between the two datasets with Pearson correlation coefficient values of 0.85 for the hourly data and 0.92 for the daily mean data. Second, INSAT-derived TCWV values are compared against GMI-derived TCWV, as these measurements are available over both land and oceans. The two datasets are regridded to $0.1^{\circ} \times 0.1^{\circ}$ for truthful comparisons. Comparison is carried out only during the GMI overpass (level 2 data). Three metrics are used for comparison: bias, correlation coefficient, and root-meansquare error (RMSE).

1) Differences in TCWV between GMI and INSAT-3D during the overpass time are used to estimate the mean bias. The positive bias represents overestimation by GMI when compared to INSAT-3D and vice versa. Overall the INSAT-3D overestimates the TCWV except at northwest India and Indo-Gangetic plains during the SWM and northwest India during the NEM. The bias is large over the north Arabian Sea and the north Bay of Bengal regions.

2) Cross-correlation coefficients are computed between the two datasets to examine the similarity in their variation. The correlations are computed only when there is a minimum number of 50 data points. It is evident from Fig. 2 that the correlations are good over land regions and relatively poor in oceanic regions, particularly over the southern Bay of Bengal. The correlation coefficients are greater than 0.8 over India and surrounding seas during the NEM and in northern plains during the SWM. Except for the southwest Bay of Bengal, where the correlation coefficient lies between 0.3 and 0.6 , other oceanic regions show correlations better than 0.6.

3) The RMSE between the two datasets reveals that the error is high over oceanic regions $(>7 \mathrm{~mm})$ and relatively less over land regions $(<5 \mathrm{~mm})$. Comprising the three metrics except over the southern Bay of Bengal region, the two datasets agree well with each other, and hence INSAT-3D-retrieved TCWV data are used for the further analysis. 
(a) TCWV Bias during SWM (GPM - INSAT-3D)

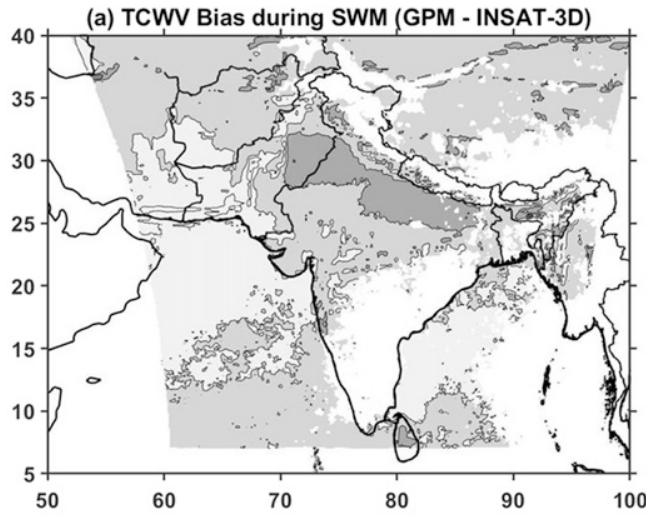

(c) TCWV correlation during SWM (INSAT-3D \& GPM)

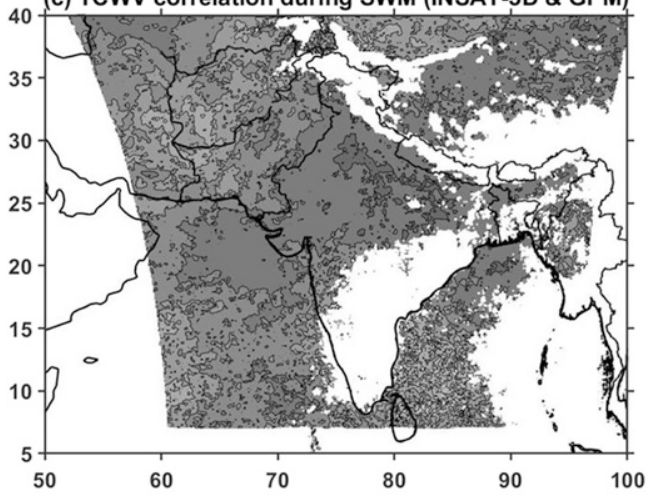

(e) TCWV RMS error during SWM (INSAT-3D \& GPM)

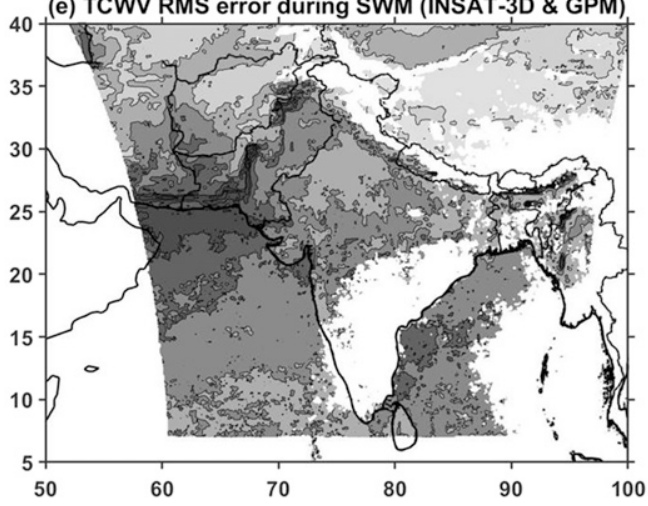

(b) TCWV Bias during NEM (GPM - INSAT-3D)
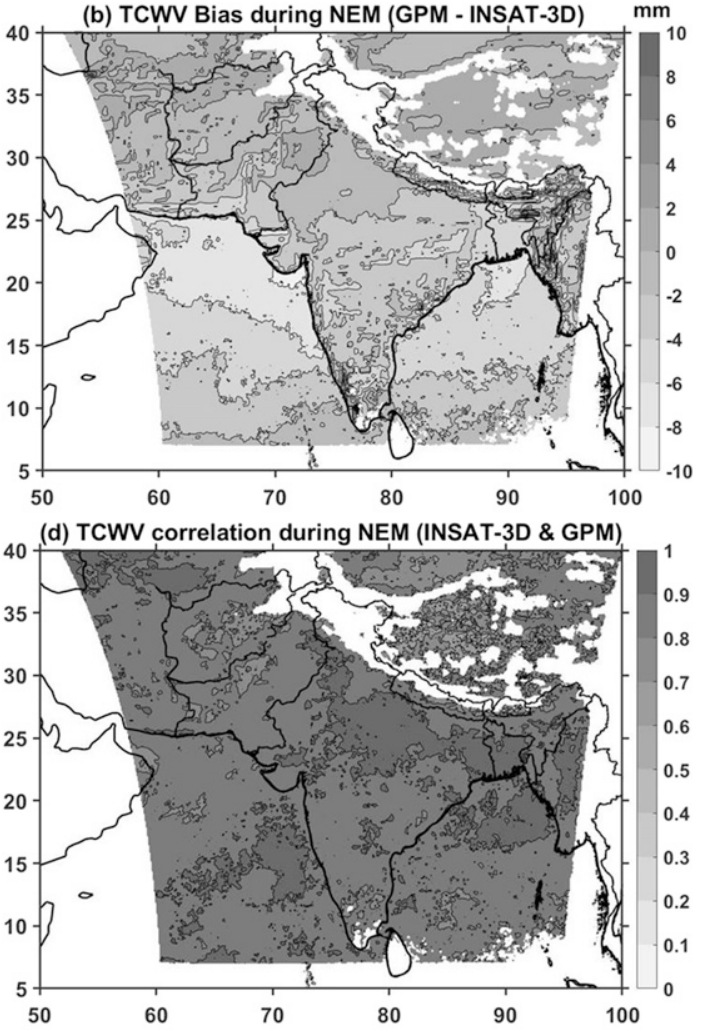

(f) TCWV RMS error during NEM (INSAT-3D \& GPM) $\mathrm{mm}$

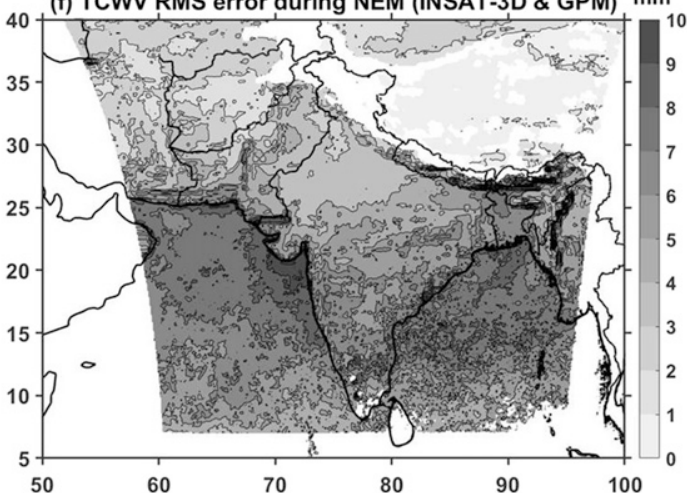

FIG. 2. Spatial distribution of TCWV bias between GMI and INSAT-3D (mm) during (a) SWM and (b) NEM seasons obtained for the period 2014-16. Positive bias indicates overestimation by GMI when compared to INSAT-3D and vice versa. Between the two datasets, (c),(d) the spatial distribution cross-correlation coefficients and (e),(f) the RMSE during SWM and NEM seasons, respectively, are shown.

The spatial distribution of seasonal mean TCWV and its spread (standard deviation) during SWM and NEM seasons estimated from INSAT-3D data for the period 2014-16 are depicted in Fig. 3. Also shown in Figs. 3a and 3c, the arrows represent the seasonal mean wind speed and direction at the $850-\mathrm{hPa}$ level. The $850-\mathrm{hPa}$ winds are chosen as a proxy for the moisture transport because most of the moisture is transported in the boundary layer of the atmosphere. The seasonal mean TCWV shows larger values over the entire India landmass and adjoining seas during the SWM than in the NEM. During the SWM, moisture is transported from the Indian Ocean to the India landmass, whereas in the NEM the continental dry airflow from the Arabian Desert results in low moisture values over the entire country except for southeast peninsular India. The SWM reversal winds (NEM winds) bring plenty of moisture from the Bay of Bengal to the southeast peninsular India during NEM season. In the entire Indian subcontinent, the maximum moisture is observed over the Bay of Bengal, Bangladesh, and Ganges basin regions during 

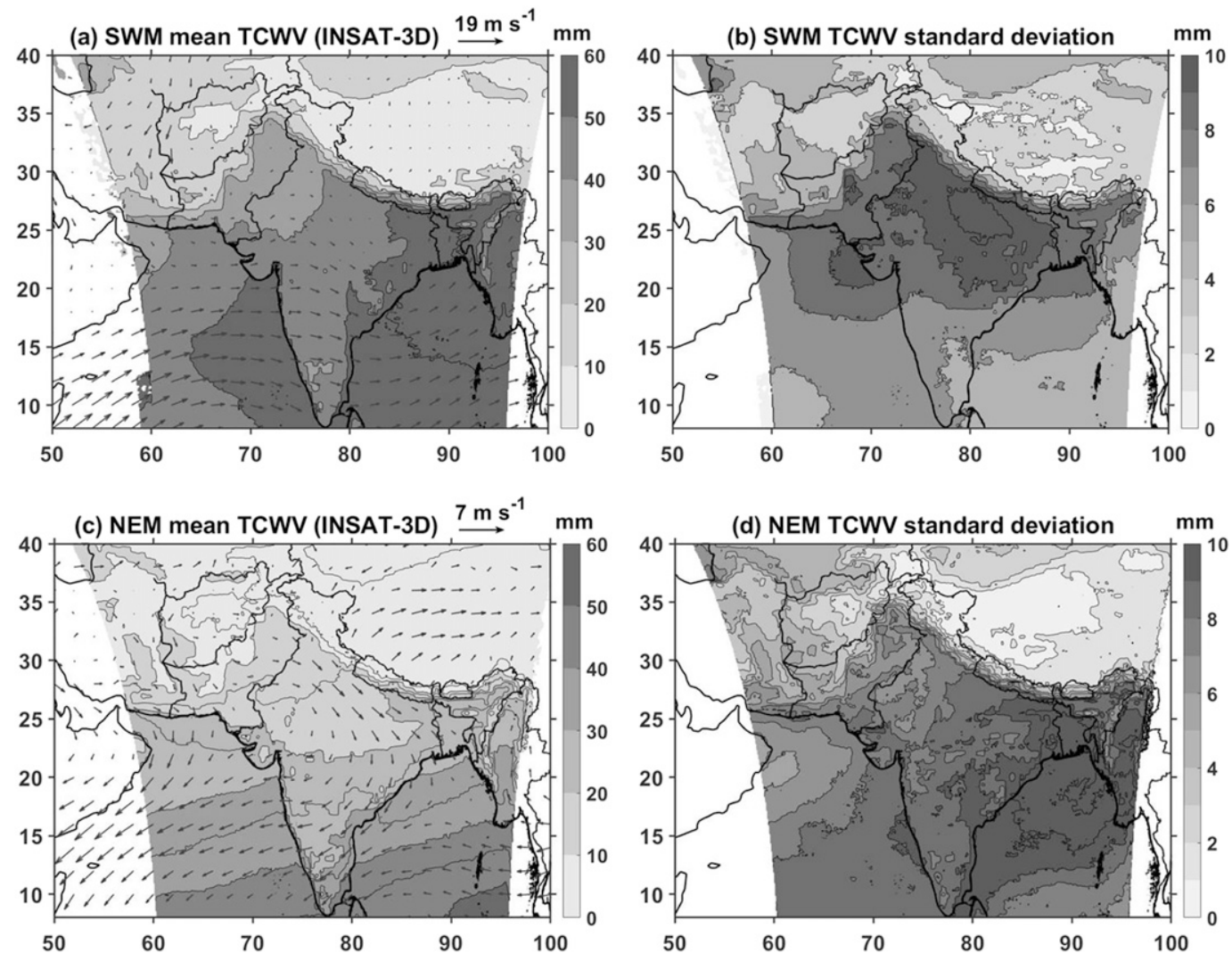

FIG. 3. Spatial distribution of mean and standard deviation of TCWV (mm) during (a),(b) SWM and (c),(d) NEM seasons obtained from INSAT-3D data for the period 2014-16. The overlaid gray arrows indicate wind speed and direction during the respective season at the $850-\mathrm{hPa}$ level.

the SWM and the minimum over north India (above $25^{\circ} \mathrm{N}$ ) during the NEM. On the other hand, the standard deviation of TCWV shows larger values during the NEM than in the SWM, indicating that though the available moisture is less, the variability is greater. The spread in TCWV is greater throughout the India landmass as well as over the Arabian Sea and Bay of Bengal during the NEM, while in the SWM the spread is greater over northwest India, Ganges basin and north Arabian Sea. Though large mean TCWV values are seen over Bay of Bengal, the low standard deviation suggests that the variability in TCWV is less during the SWM.

The observed TCWV standard deviation over a given location is the combined effect of diurnal, intraseasonal, and interseasonal variations. To quantify the diurnal cycle contribution in the observed standard deviation, first, the hourly data of TCWV are subtracted from the mean of that day at a given location and the estimated the standard deviation and are depicted in Figs. $4 \mathrm{a}$ and $4 \mathrm{~b}$. The diurnal cycle can cause spread in TCWV up to $4.5 \mathrm{~mm}$ during the SWM season over the India landmass and adjoining seas and less than $3.5 \mathrm{~mm}$ during the NEM season. The magnitude of diurnal cycle variance of TCWV is large along the west coast of India and western Bay of Bengal (along the east coast of India) during the SWM and in southeast peninsular India and southern Bay of Bengal during the NEM. The contributions of intraseasonal variation of TCWV have been estimated by considering the deviations of daily data from the respective seasonal mean at a given location. These deviations are further used to compute standard deviations, and the estimated standard deviations are shown in Figs. $4 \mathrm{c}$ and $4 \mathrm{~d}$. The large standard deviation values $(>8 \mathrm{~mm})$ over the entire India landmass and northern parts of the Arabian Sea and Bay of Bengal, except the southern peninsular India region, show huge intraseasonal variability in TCWV during SWM. Prasad et al. (2007) also showed that the Kanpur (Indian Institute of Technology, Kanpur) GPS station shows high intraseasonal fluctuations in TCWV when compared to the stations in southern peninsular India (Hyderabad and IISC) during SWM that corroborate the findings of INSAT-3D. On the other hand, the intraseasonal fluctuations of TCWV are high $(>8 \mathrm{~mm})$ throughout the Indian subcontinent and are further high $(\sim 10 \mathrm{~mm})$ over the northern Bay of Bengal during the NEM. The interseasonal variations (not shown here) are less than $1 \mathrm{~mm}$ 
(a) TCWV diurnal variation during SWM (INSAT3D)

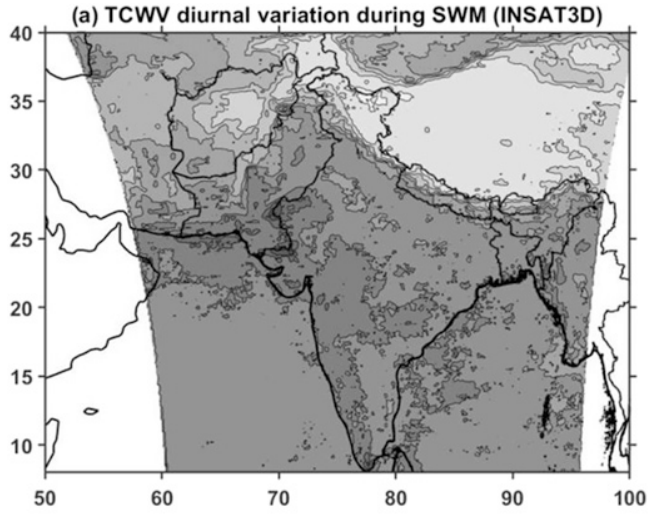

(c) TCWV intraseasonal variation during SWM (INSAT3D)

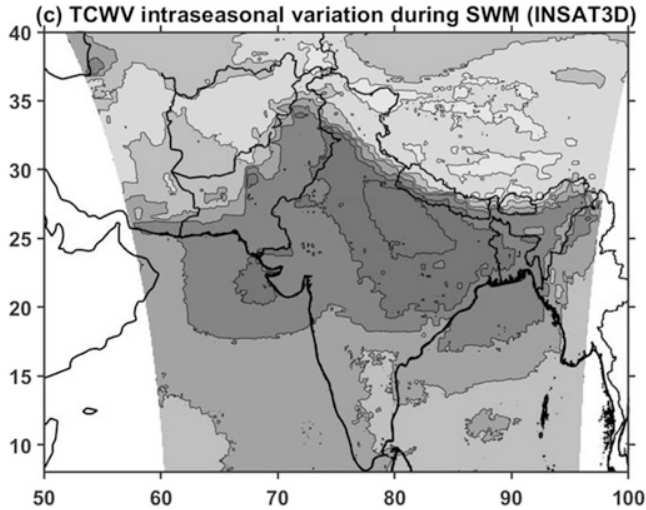

(b) TCWV diurnal variation during NEM (INSAT3D)

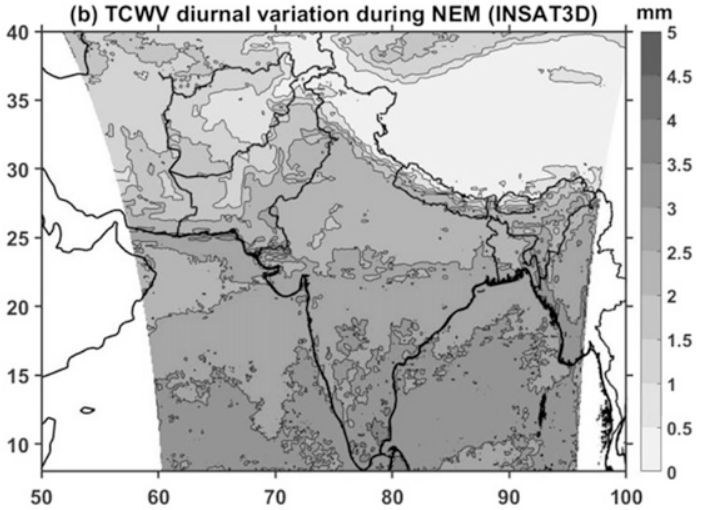

(d) TCWV intraseasonal variation during NEM (INSAT3D) $\mathrm{mm}$

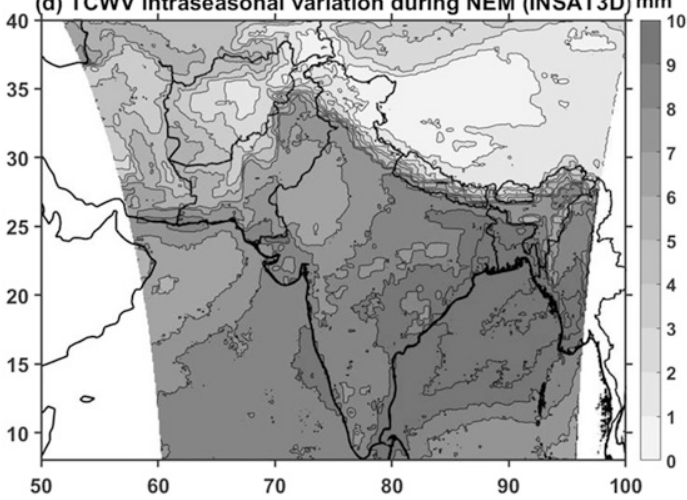

FIG. 4. Spatial distribution of contributions of (top) diurnal and (bottom) intraseasonal variations in the standard deviation of TCWV (mm) during the (a),(c) SWM and (b),(d) NEM seasons obtained from INSAT-3D data for the period 2014-16.

during both the monsoon seasons over the entire India region except some parts of central India and the Ganges basin during the SWM, whereas there is moderate variability $(\sim 3 \mathrm{~mm})$ over the southern Bay of Bengal and Tamil Nadu province during the NEM.

To assess quantitatively the contributions of different modes to the observed seasonal variance in TCWV, a Lomb-Scargle periodogram (LSP) analysis is performed. Statistically significant (at the $95 \%$ level) modes between 3 and 8 days (synoptic scale), between 10 and 20 days, and between 30 and 60 days (MJO scales), following Goswami and Mohan (2001) and Rajeevan et al. (2012), are identified. Their contributions to the total variance are quantified during the SWM and NEM and are shown in Fig. 5. Overall, the 30-60-day and 10-20-day oscillations account for most of the total TCWV variance over the Indian subcontinent in both seasons. During the SWM season, 30-60-day oscillations contribute $30 \%-40 \%$ to the observed variance in TCWV over the Bay of Bengal, south Arabian Sea, eastern India, Bangladesh, Myanmar, and southern peninsular India, while contributing only $10 \%-20 \%$ in central and western India and north Arabian Sea. The 10-20-day oscillations account for $30 \%-40 \%$ of the total variance over the south Arabian Sea, southern peninsular India, the Bay of Bengal, and Myanmar and account for $10 \%-20 \%$ over other monsoon regions. However, during the NEM both 10-20-day and 30-60-day oscillations contribute $20 \%-30 \%$ to the total variance over the entire Indian landmass and adjoining seas. The 3-8-day synoptic-scale oscillations are not prominently seen over India but rather appear in patches along the east coast of India during the SWM.

To quantify the contributions of diurnal and semidiurnal cycles to the total variance, the LSP analysis is performed on the hourly data to obtain the amplitude and variance of the above components, whenever they are found to be significant (at the $95 \%$ confidence level). These estimated contributions during the SWM and NEM are plotted in Fig. 6. The diurnal (semidiurnal) component contributes $30 \%-40 \%(20 \%-30 \%)$ to the total variance in TCWV over southern peninsular India, south Bay of Bengal, and Myanmar regions and less than $20 \%(10 \%)$ over other parts of Indian subcontinent during the SWM season. However, during the NEM season the diurnal component contributes $\sim 20 \%$ to the 
(a) 03 - 08 day

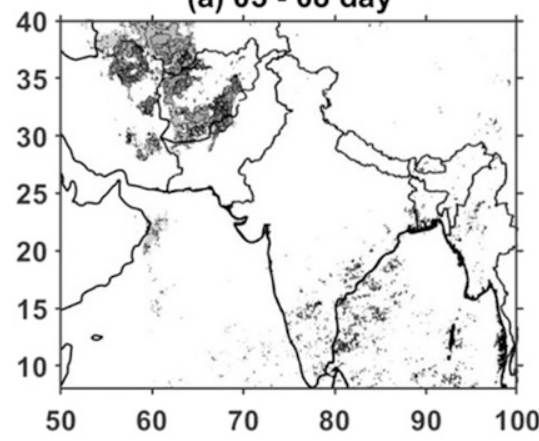

(d) 03 - 08 day

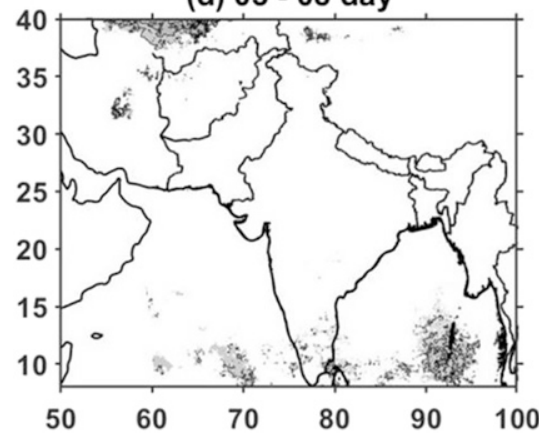

SWM

(b) 10 - 20 day

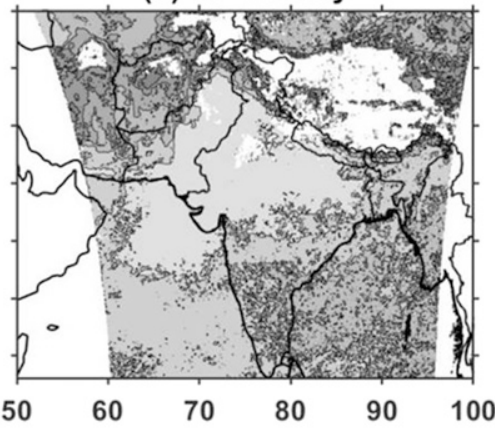

NEM

(e) 10 - 20 day

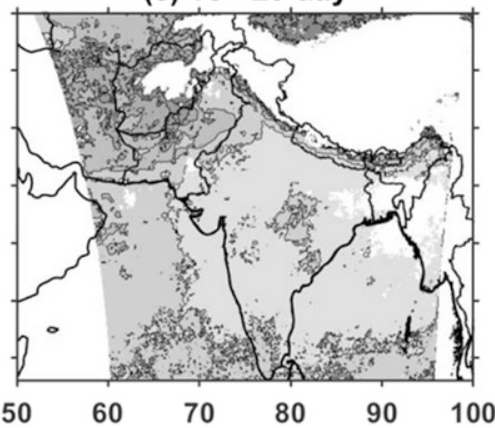

(c) 30 - 60 day

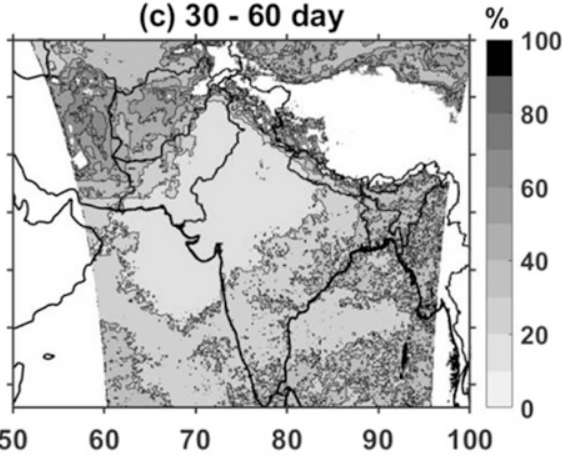
100

30

60
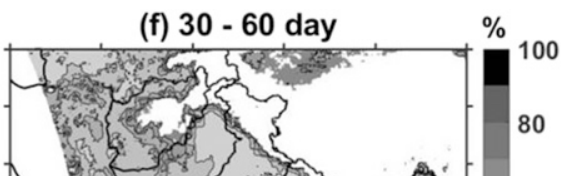

60

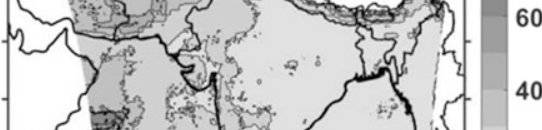

20

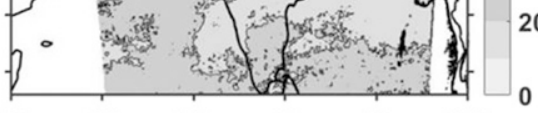

00

FIG. 5. Spatial distribution of contributions of (left) 3-8-day, (center) 10-20-day, and (right) 30-60-day oscillations in the standard deviations of TCWV (\%) during the (a)-(c) SWM season and (d)-(f) NEM season. Standard deviations of each mode are estimated only when the amplitudes are above $95 \%$ statistically significant.

total variance over the entire landmass of India and the Arabian Sea and less than $10 \%$ over the Bay of Bengal. The semidiurnal component contributes $\sim 10 \%$ to the total variance over the Indian subcontinent.

To illustrate the close association between the spatial variation of precipitation and TCWV, the seasonal mean accumulated rainfall for the study period is computed and depicted in Fig. 7. Corroborating the rainfall maps shown in Saikranthi et al. (2018), a copious amount of rainfall is observed along the Western Ghats and the west coast of Myanmar and a moderate amount of rainfall in the Bay of Bengal, central India, and the foothills of Himalayas during the SWM season. On the other hand, maximum rainfall is observed in southeast peninsular India, the southern Arabian Sea, and the Bay of Bengal during the NEM season. It is clear from Figs. 3 and 7 that, except over the Arabian Sea and southern Myanmar regions, more TCWV results in plenty of rainfall at the surface.

At a given point, the spatial coherency of TCWV and rainfall are estimated following two steps. First, the Pearson correlation coefficient $r$ with respect to surrounding grids $(<500 \mathrm{~km}$ in distance) are computed only when both grids have TCWV data and at least one grid should have rainfall data. The data points with no rainfall $(0 \mathrm{~mm})$ at both grids are discarded while computing the Pearson correlation coefficient. The arbitrary distance $500 \mathrm{~km}$ is chosen to reduce the computational load. When the data points are more than 100 then, as a second step, the spatial correlation distance $d_{0}$ is estimated by fitting an exponential function as follows:

$$
\rho(d)=\rho_{0} \times \exp \left[-\left(\frac{d}{d_{0}}\right)\right]
$$

where $\rho_{0}$ is the nugget parameter indicating the correlation value for the near-zero distances, which is due to random instrumental errors, $d$ is the distance between the two grid points, and $d_{0}$ is the correlation distance (or the spatial decorrelation scale, i.e., 1/e-folding distance).

The $d_{0}$ values estimated by fitting (1) to the daily mean TCWV data of INSAT-3D during SWM and NEM seasons are depicted in Fig. 8. The large $d_{0}$ values observed over north India (above $20^{\circ} \mathrm{N}$ ) indicate high special coherency in daily mean TCWV during both the monsoon seasons but show a decreasing pattern from north to south. The spatial coherency of daily mean TCWV is less during the SWM than in the NEM over southern peninsular India, the south Bay of Bengal 


\section{SWM}

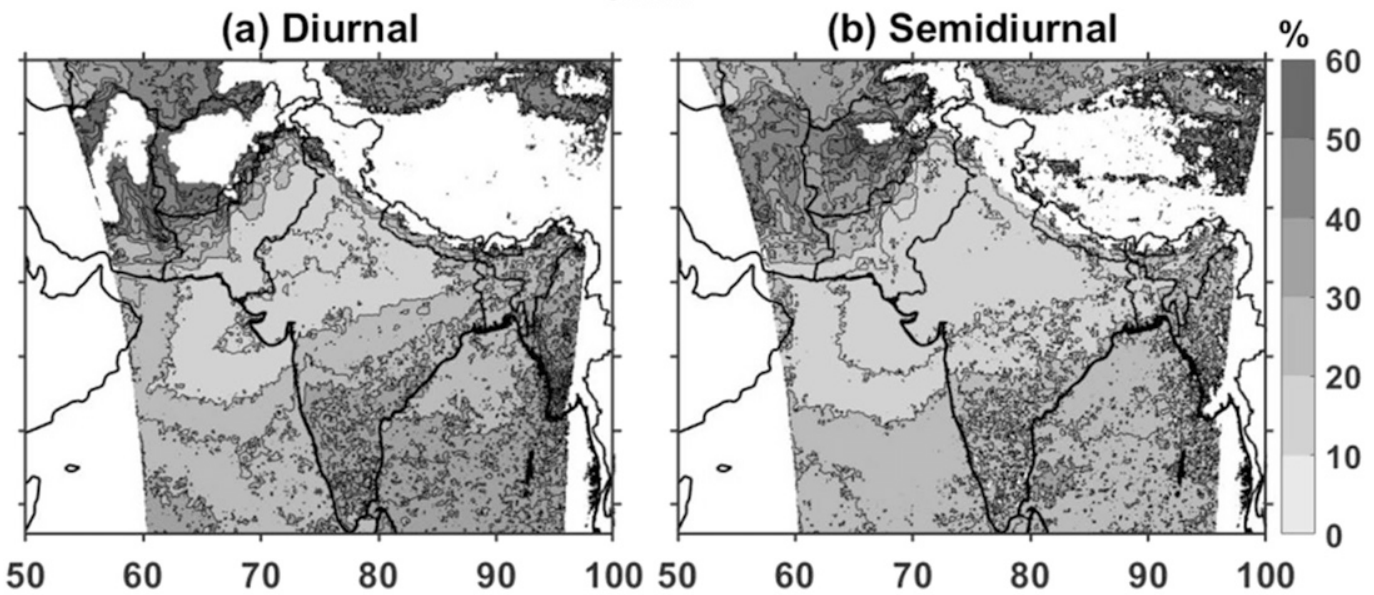

NEM

(c) Diurnal

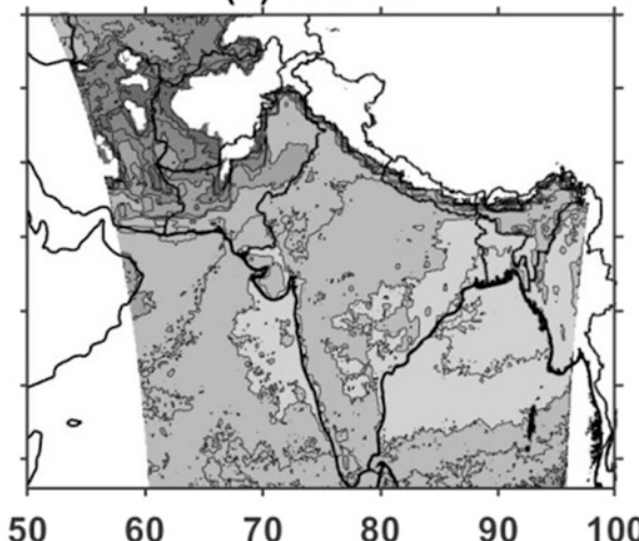

(d) Semidiurnal

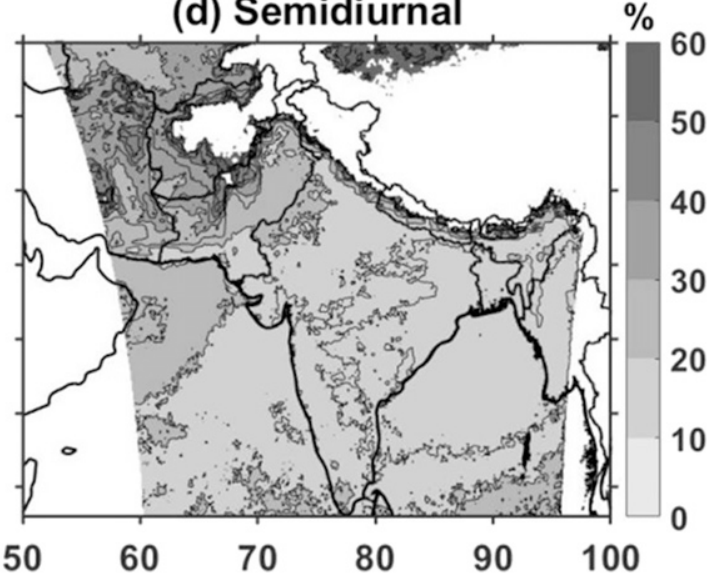

FIG. 6. Spatial distribution of contributions of (left) 24- and (right) 12-h oscillations in the standard deviations of TCWV (\%) during the (a),(b) SWM season and (c),(d) NEM season. Standard deviations of each mode are estimated only when the amplitudes are above $95 \%$ statistically significant.

region (the two driest regions during SWM), and the eastern India, Bangladesh, and Myanmar regions.

To check the link between spatial homogeneity of TCWV and rainfall, $d_{0}$ values have been computed for the daily rainfall data from (1) and are depicted in Fig. 9. The spatial coherency in rainfall over the Indian subcontinent during both the monsoon seasons is $\sim 10$ times less than the TCWV except in the central India region during the NEM. Unlike TCWV, the $d_{0}$ patterns of rainfall are distinctly different over the Indian subcontinent except over the Arabian Sea. Though the TCWV shows high spatial homogeneity in the IndoGangetic plains during SWM, the rainfall is highly inhomogeneous (low $d_{0}$ ) and in turn results in small areal extent homogeneous rainfall zones as identified in Gadgil et al. (1993), Satyanarayana and Srinivas (2008), and Saikranthi et al. (2013). However, over the central
India region, the large $d_{0}$ results in high spatial homogeneity in the rainfall, which in turn produces a large areal extent of homogeneous rainfall zones during both the monsoon seasons, corroborating the findings of Saikranthi et al. (2013). When compared to SWM, the $d_{0}$ values are further larger in the central India region during the NEM. Though the $d_{0}$ values of TCWV are smaller over the Bay of Bengal than the surrounding areas, the $d_{0}$ values of rainfall are larger during both the seasons. In comparison with the Bay of Bengal, the homogeneity in rainfall is more over the Arabian Sea during the SWM and nearly the same during the NEM.

The variation of TCWV and rainfall at smaller time scales (diurnal variation) is elucidated with the help of hourly data. The $d_{0}$ values obtained by fitting (1) to the hourly TCWV and rainfall datasets are depicted in Figs. 10 and 11 , respectively. Compared to daily TCWV values, the 
(a) SWM Rainfall (IMERG)

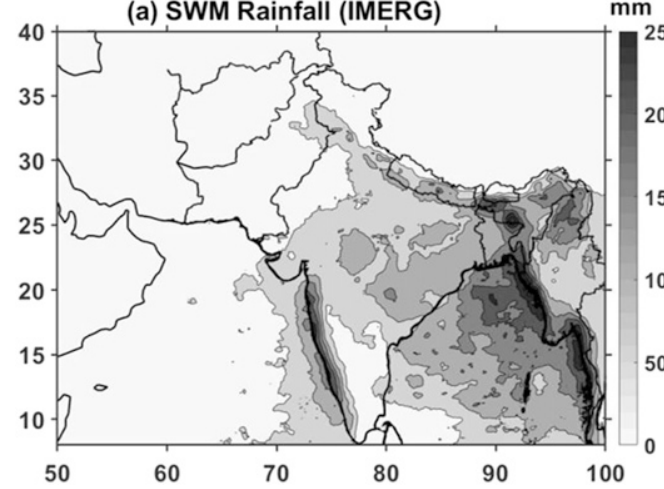

(b) NEM Rainfall (IMERG)

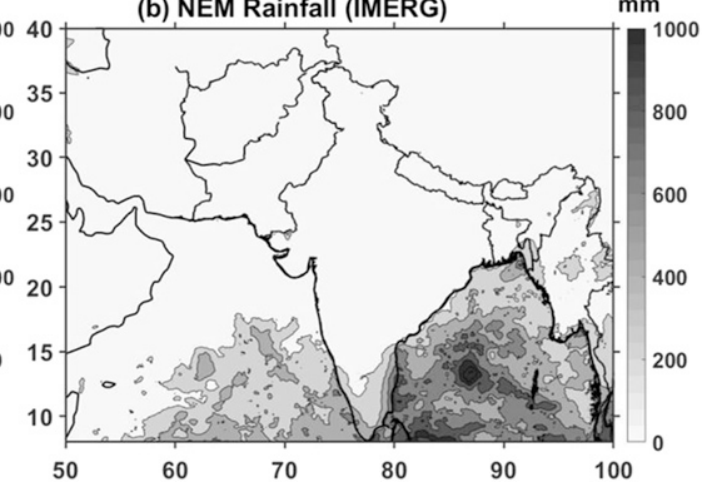

FIG. 7. (a) Spatial distribution of accumulated rainfall $(\mathrm{mm})$ during the SWM season obtained from IMERG data for the period 2014-16. (b) As in (a), but for the NEM season.

hourly values decrease the spatial correlation lengths during both the monsoon seasons. As expected, this indicates the greater unevenness of water vapor at smaller temporal scales. The decrease in $d_{0}$ is significant in northwest India during the SWM and over the northern Bay of Bengal in the NEM. Similar to TCWV, the diurnal cycle of rainfall also reduces the spatial homogeneity in both the monsoon seasons by a factor of $\sim 3$.

\section{Summary and discussion}

The variability of TCWV over a given region is a result of transport of moisture, evapotranspiration, and precipitation. During the SWM, the transport of moisture is mainly through the monsoonal winds while in NEM, the dry air flows from the Arabian Desert to the Indian landmass except for southern peninsular India. Utilizing satellite measurements, Goroshi et al. (2017) showed that the evapotranspiration is greater ( $>250 \mathrm{~mm}$ per season) along the foothills of the Himalayas, Western Ghats, and northeastern India and nearly uniform over central India and the Indo-Gangetic plains with a mean value $<130 \mathrm{~mm}$ per season and a minimum over Rajasthan province during the SWM. They also showed that the evapotranspiration is maximum during the NEM when compared to other seasons over the entire India landmass with maximum evapotranspiration $(>300 \mathrm{~mm}$ per season) along the Western Ghats and central India regions and a minimum over Rajastan province. The evapotranspiration patterns shown in Goroshi et al. (2017) clearly indicate that this process is occurring at large spatial scales during both the monsoon seasons.

The sink mechanism of atmospheric TCWV is precipitation. The climatological occurrences of different kinds of precipitation during SWM and NEM over the Indian subcontinent have been estimated using TRMMPR 2A25 data for the period 1998-2013 and are depicted in Fig. 12. The occurrence of convective rain is higher $(>25 \%)$ in northwest India, the foothills of the Himalayas, the Ganges basin, and southeast peninsular India during the SWM and along the west coast of India and western parts of central India regions during the NEM.
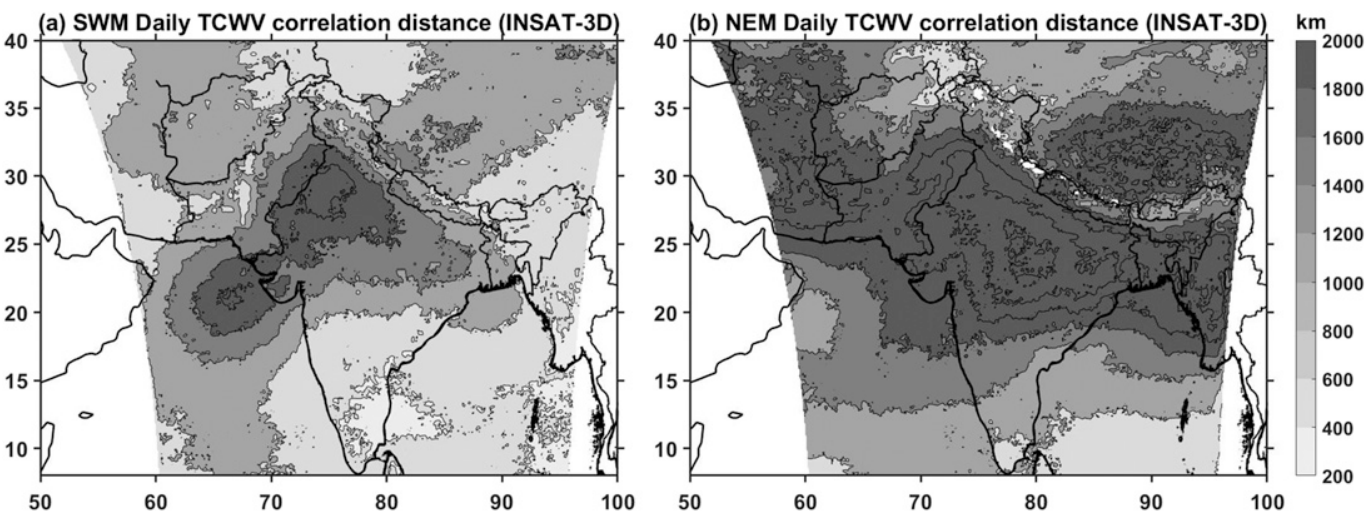

FIG. 8. Spatial distribution of TCWV correlation distance (km) during (a) SWM and (b) NEM seasons estimated from INSAT-3D daily mean data for the period 2014-16. 

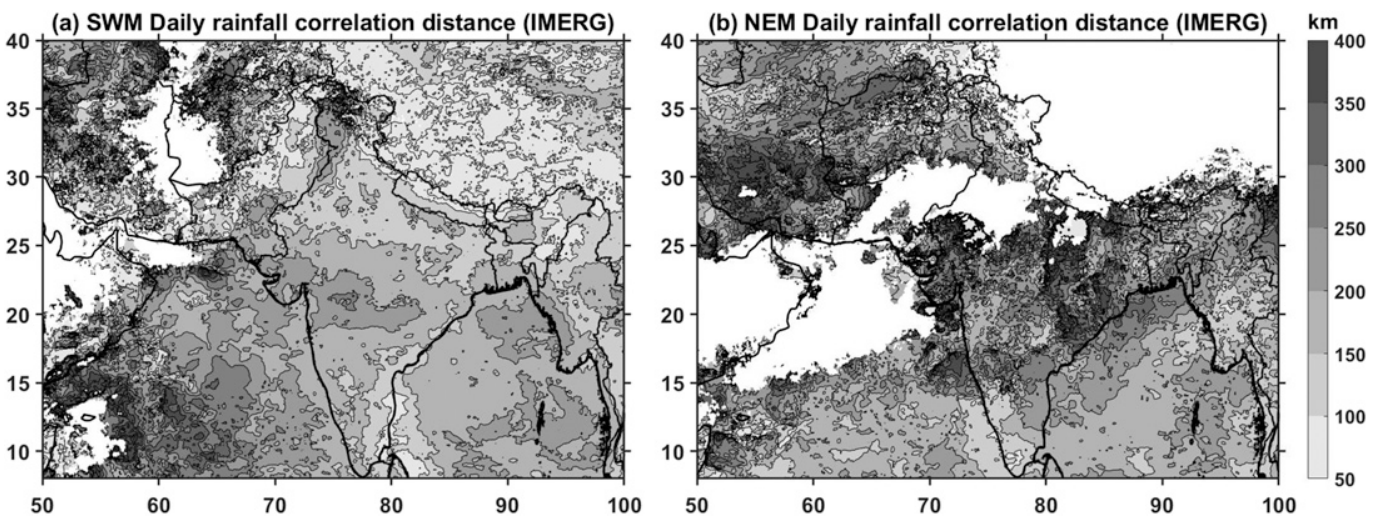

FIG. 9. Spatial distribution of rainfall correlation distance $(\mathrm{km})$ during (a) SWM and (b) NEM seasons estimated from IMERG daily data for the period 2014-16.

The decrease in convective rain occurrence is significant over northwest India and the Indo-Gangetic plains during the NEM ( $15 \%)$. More than $65 \%$ of the precipitation occurs in the form of stratiform rain during SWM except over the Arabian Sea and Western Ghats regions, substantiating the findings of Schumacher and Houze (2003), Romatschke and Houze (2011), Saikranthi et al. (2014), and Houze et al. (2015). On the other hand, during NEM, the stratiform rain occurrence is $>75 \%$ over IndoGangetic plains and northwest India regions and $>60 \%$ over central India and south peninsular India regions (Saikranthi 2014). When compared to SWM, the occurrence of stratiform rain increases over the Arabian Sea and Western Ghats regions during NEM. The shallow rain occurrence is abundant $(>40 \%)$ over the Arabian Sea and Western Ghats during SWM while it decreases during NEM but the reduction is considerable over the Western Ghats $(<20 \%)$. The occurrence of shallow rain increases over the Bay of Bengal and decreases over the Indo-Gangetic plains by $\sim 10 \%$ during the NEM than in the SWM. The occurrence of source and sink processes at large spatial scales results in high spatial homogeneity in TCWV during both the monsoon seasons over central India and the Indo-Gangetic plains (Figs. 7a, 8a). When compared to SWM, the decrease in occurrence of smallscale processes (convective rain) further enhances the spatial homogeneity in TCWV over these two regions. Along the west coast of India, though the convective rain occurrence is higher in the NEM, the increased stratiform rain occurrence along with the uniform distribution of evapotranspiration enlarges the TCWV homogeneity.

The rainfall spatial coherency mainly depends on the occurrence of small- and large-scale precipitating systems. By the nature of precipitating systems, convective rain occurs at small spatial scales while stratiform rain occurs at large spatial scales. In general, over oceans these rain types are associated with mesoscale convective complexes or depressions/cyclones (Houze et al. 2015). The tracks of depressions and cyclones formed over the Arabian Sea and the Bay of Bengal during the study period (not shown here) portray that most of the depressions/cyclones have formed in the northern parts of the Bay of Bengal and the (a) SWM 1h TCWV correlation distance (INSAT-3D)

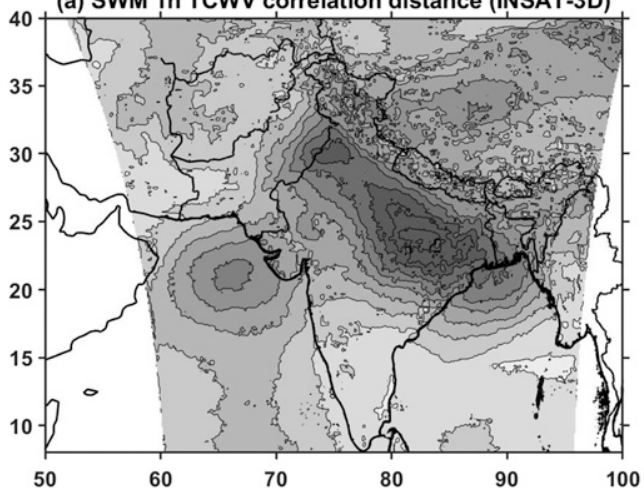

(b) NEM 1h TCWV correlation distance (INSAT-3D)

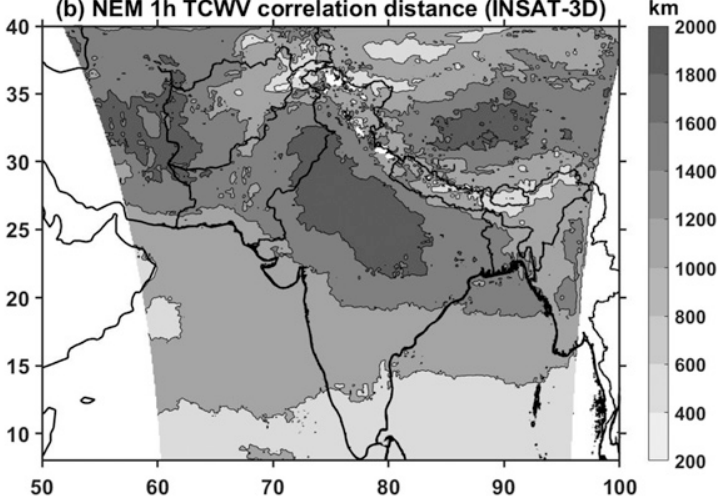

FIG. 10. As in Fig. 5, but for the INSAT-3D hourly TCWV data during the period 2014-16. 

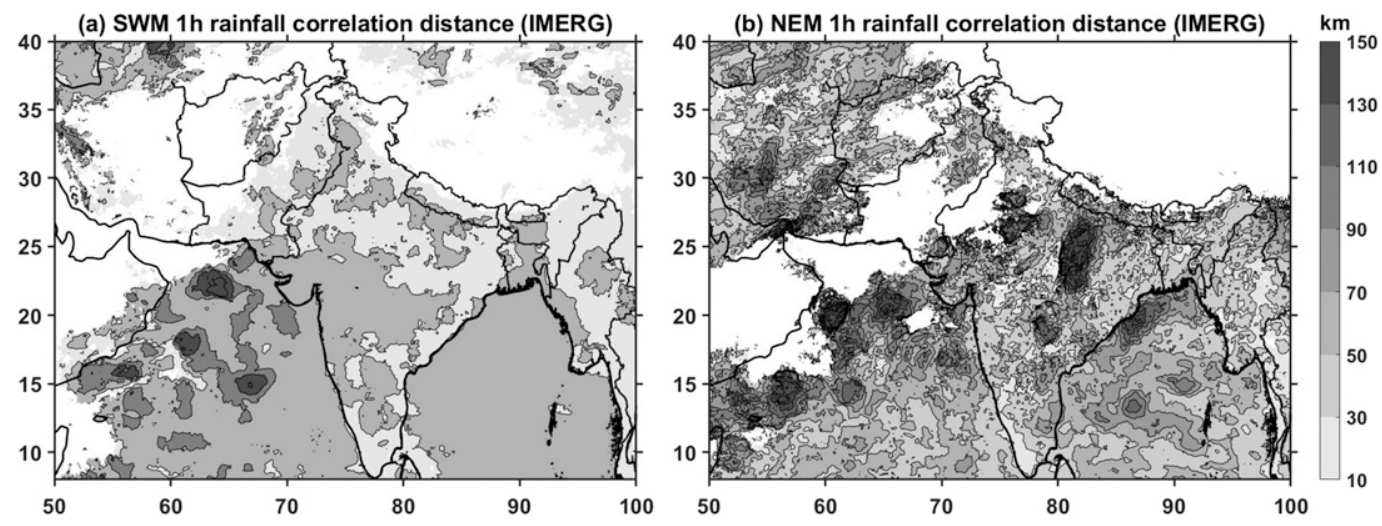

FIG. 11. As in Fig. 6, but for the IMERG hourly rainfall data during the period 2014-16.

Arabian Sea during the SWM. The systems that are formed in the Bay of Bengal moved toward central India and the Indo-Gangetic plains while in the Arabian Sea they moved farther north. On the other hand, during NEM, most of the depressions/cyclones that form in the southern part of the Bay of Bengal move toward southern peninsular India, while in the Arabian Sea they move north or west. The high occurrence of stratiform rain and large-scale precipitating systems over the Bay of Bengal results in large $d_{0}$ values for rainfall during both the monsoon seasons. Though the climatological occurrence of stratiform rain is greater and convective rain is less in SWM than in NEM, the $d_{0}$ values of rainfall are large in NEM since the occurrence of depressions/cyclones is greater in NEM than in SWM during the study period, which can alter the $d_{0}$ values. In general, the amount of

SWM climatology (1998-2013)

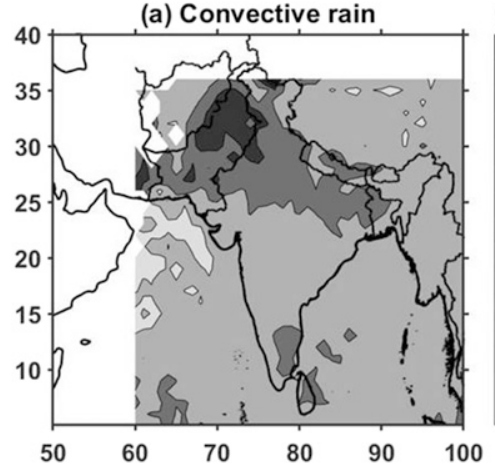

(d) Convective rain

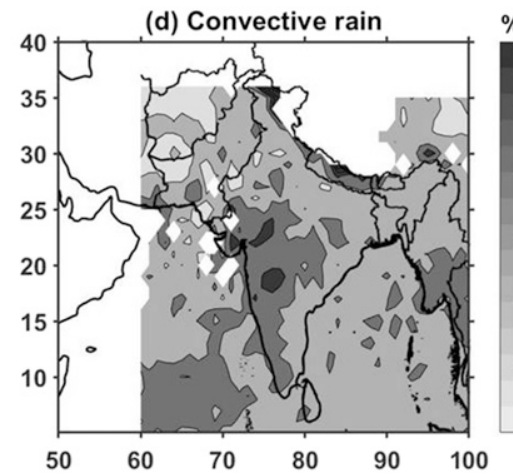

(b) Stratiform rain

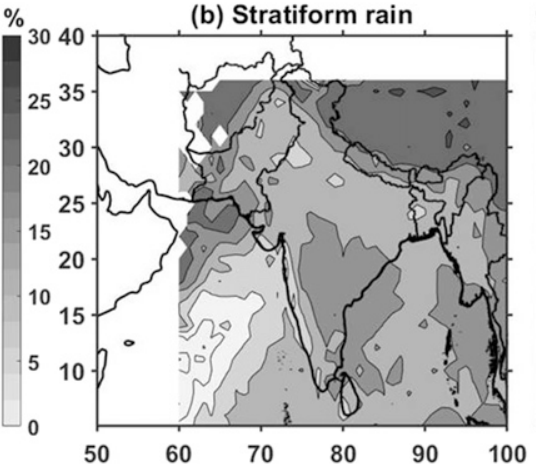

NEM climatology (1998-2013)

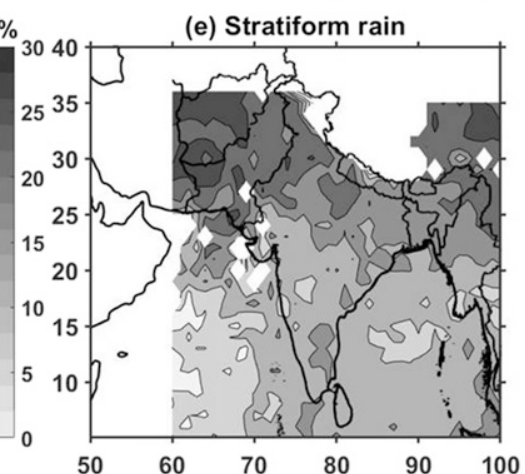

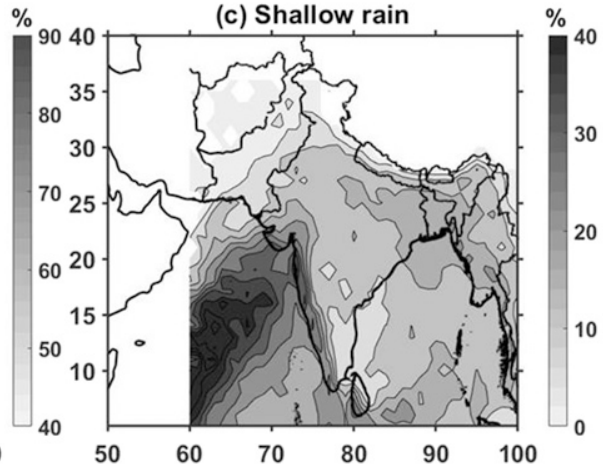

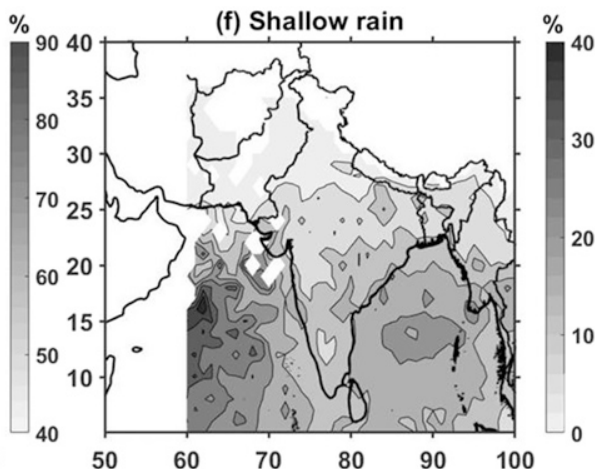

FIG. 12. Spatial distribution of occurrence of (left) convective, (center) stratiform, and (right) shallow rain during the (a)-(c) SWM and (d)-(f) NEM seasons estimated from TRMM-PR 2A25 version 7 data for the period 1998-2013. 
rainfall observed over the north Arabian Sea is much less due to presence of strong temperature inversions over this region. The maximum amount of observed rainfall during the study period over this region is mainly from the passages of depressions/cyclones, which in turn produce large $d_{0}$ values for rainfall. Though the stratiform rain occurrence is $>60 \%$ over the Indo-Gangetic plains and northwest India regions during SWM, the high occurrence of convective rain reduces the spatial coherency in rainfall. Nevertheless, a substantial reduction in convective rain and an increase in stratiform rain occurrence increases the rainfall spatial coherency over these regions during the NEM. In the case of central India, the passage of depressions/ cyclones results in large $d_{0}$ values during the SWM monsoon season. The apparent decrease in spatial coherence in regions of high rainfall may be partly due to the lack of TCWV measurements in rainy conditions.

The present analysis reveals that over the Indian subcontinent the spatial decorrelation is $\sim 10$ times less for rainfall than the TCWV. The larger TCWV spatial decorrelation distance results in bigger homogeneous rainfall zones, except over the Indo-Gangetic plains and northwest India regions. On the whole, the 30-60-day MJO-scale oscillations contribute more to the observed variance in TCWV during both the monsoon seasons. In a few regions, like southern peninsular India, Myanmar, and eastern India, the 10-20-day oscillations and 24-h diurnal cycle also contribute considerably to the total variance in TCWV. The shape of the correlation function useful for the area-point variances is given in the online supplemental material.

Acknowledgments. The authors thank the Meteorological and Oceanographic Satellite Data Archival Centre (https://www.mosdac.gov.in/) for providing the INSAT-3D data, the SuomiNet team for providing the GPS TCWV at the Bangalore site (IISC), the GPM (ftp:// arthurhou.pps.eosdis.nasa.gov) team for IMERG rainfall data and TCWV data, the ECMWF (http://data-portal. ecmwf.int/) team for providing the ERA data, and Prof. Robert Houze and his team for the interpolated 3D gridded TRMM-PR data (http://trmm.atmos.washington. edu). We thank the anonymous reviewers for their critical review in improving the quality of the work.

\section{REFERENCES}

Ackerman, S. A., K. I. Strabala, W. P. Menzel, R. A. Frey, C. C. Moeller, and L. E. Gumley, 1998: Discriminating clear sky from clouds with MODIS. J. Geophys. Res., 103, 32 141-32 157, https://doi.org/ 10.1029/1998JD200032.

Ahmed, F., and C. Schumacher, 2015: Convective and stratiform components of the precipitation-moisture relationship. Geophys. Res. Lett., 42, 10 453-10 462, https://doi.org/10.1002/2015GL066957.
Braun, J., and T. Van Hove, 2005: Recent improvements in the retrieval of precipitable water vapor. ION GNSS 2005, Long Beach, CA, Institute of Navigation, 298-301, https://www.ion.org/ publications/abstract.cfm?articleID $=6220$.

Bretherton, C. S., M. E. Peters, and L. E. Back, 2004: Relationships between water vapor path and precipitation over the tropical oceans. J. Climate, 17, 1517-1528, https://doi.org/ 10.1175/1520-0442(2004)017<1517:RBWVPA > 2.0.CO;2.

Brown, D. W., S. J. Clarke, and J. Zabransky, 2002: A regional comparison of GPS atmospheric moisture measurements at Plymouth and Bartlett, New Hampshire. Preprints, Symp. on Observations, Data Assimilation, and Probabilistic Prediction, Orlando, FL, Amer. Meteor. Soc., P2.5, https://ams.confex. com/ams/pdfpapers/26296.pdf.

Brown, R. G., and C. Zhang, 1997: Variability of midtropospheric moisture and its effect on cloud-top height distribution during TOGA COARE. J. Atmos. Sci., 54, 2760-2774, https://doi.org/ 10.1175/1520-0469(1997)054<2760:VOMMAI >2.0.CO;2.

Dach, R., U. Hugentobler, P. Fridez, and M. Meindl, Eds., 2007: Bernese GPS software version 5.0. Astronomical Institute of the University of Bern, 612 pp., http://www.bernese.unibe.ch.

Dai, A., J. Wang, R. H. Ware, and T. Van Hove, 2002: Diurnal variation in water vapor over North America and its implications for sampling errors in radiosonde humidity. J. Geophys. Res., 107, 4090, https://doi.org/10.1029/2001JD000642.

Derbyshire, S. H., I. Beau, P. Bechtold, J.-Y. Gandpeix, J.-M. Piriou, J.-L. Redelsperger, and P. Soares, 2004: Sensitivity of moist convection to environmental humidity. Quart. J. Roy. Meteor. Soc., 130, 3055-3079, https://doi.org/10.1256/qj.03.130.

Dumont, D. M., and J. Zabransky, 2001: A comparison of GPS measured precipitable water at Bartlett, $\mathrm{NH}$ with radiosonde measurements in the Northeast. Preprints, 11th Symp. on Meteorological Observations and Instrumentation, Albuquerque, NM, Amer. Meteor. Soc., 245-247.

Gadgil, S., Yadumani, and N. V. Joshi, 1993: Coherent rainfall zones of the Indian region. Int. J. Climatol., 13, 547-566, https://doi.org/10.1002/joc.3370130506.

Gong, J., and D. L. Wu, 2017: Microphysical properties of frozen particles inferred from Global Precipitation Measurement (GPM) Microwave Imager (GMI) polarimetric measurements. Atmos. Chem. Phys., 17, 2741-2757, https://doi.org/ 10.5194/acp-17-2741-2017.

Goroshi, S., R. Pradhan, R. P. Singh, K. K. Singh, and J. S. Parihar, 2017: Trend analysis of evapotranspiration over India: Observed from long-term satellite measurements. J. Earth Syst. Sci., 126, https://doi.org/10.1007/s12040-017-0891-2.

Goswami, B. N., and R. S. A. Mohan, 2001: Intraseasonal oscillations and interannual variability of the Indian summer monsoon. J. Climate, 14, 1180-1198, https://doi.org/10.1175/ 1520-0442(2001)014<1180:IOAIVO > 2.0.CO;2.

Holloway, C. E., and J. D. Neelin, 2009: Moisture vertical structure, column water vapor, and tropical deep convection. J. Atmos. Sci., 66, 1665-1683, https://doi.org/10.1175/2008JAS2806.1.

— and - 2010: Temporal relations of column water vapor and tropical precipitation. J. Atmos. Sci., 67, 1091-1105, https://doi.org/10.1175/2009JAS3284.1.

Houze, R. A., Jr., K. L. Rasmussen, M. D. Zuluaga, and S. R. Brodzik, 2015: The variable nature of convection in the tropics and subtropics: A legacy of 16 years of the Tropical rainfall measuring mission satellite. Rev. Geophys., 53, https://doi.org/ 10.1002/2015RG000488.

Huffman, G. J., D. T. Bolvin, and E. J. Nelkin, 2017: Integrated MultisatellitE Retrievals for GPM (IMERG) technical documentation. 
NASA Tech. Doc., 54 pp., https://pmm.nasa.gov/sites/default/ files/document_files/IMERG_technical_doc_3_22_17.pdf.

Jensen, M. P., and A. D. Del Genio, 2006: Factors limiting convective cloud-top height at the ARM Nauru Island climate research facility. J. Climate, 19, 2105-2117, https://doi.org/10.1175/JCLI3722.1.

Katti, V. R., V. R. Pratap, R. K. Dave, and K. N. Mankad, 2006: INSAT-3D: An advanced meteorological mission over Indian Ocean. Proc. SPIE, 6407, 640709, https://doi.org/10.1117/12.697880.

Kay, M. J., and M. Box, 2000: Radiative effects of absorbing aerosols and the impact of water vapor. J. Geophys. Res., 105, 12 221-12 234, https://doi.org/10.1029/2000JD900065.

Klingaman, N. P., and Coauthors, 2015: Vertical structure and physical processes of the Madden-Julian oscillation: Linking hindcast fidelity to simulated diabatic heating and moistening. J. Geophys. Res. Atmos., 120, 4690-4717, https://doi.org/10.1002/2014JD022374.

Kuo, Y., J. D. Neelin, and C. R. Mechoso, 2017: Tropical convective transition statistics and causality in the water vaporprecipitation relation. J. Atmos. Sci., 74, 915-931, https:// doi.org/10.1175/JAS-D-16-0182.1.

Li, J., W. W. Wolf, W. P. Menzel, W. Zhang, H. L. Huang, and T. H. Achtor, 2000: Global soundings of the atmosphere from ATOVS measurements: The algorithm and validation. J. Appl. Meteor., 39, 1248-1268, https://doi.org/10.1175/1520-0450(2000) 039<1248:GSOTAF $>2.0$. CO;2.

Lintner, B. R., C. E. Holloway, and J. D. Neelin, 2011: Column water vapor statistics and their relationship to deep convection, vertical and horizontal circulation, and moisture structure at Nauru. J. Climate, 24, 5454-5466, https://doi.org/ 10.1175/JCLI-D-10-05015.1.

Ma, X. L., T. Schmit, and W. Smith, 1999: A non-linear physical retrieval algorithm - Its application to the GOES-8/9 sounder. J. Appl. Meteor., 38, 501-503, https://doi.org/10.1175/ 1520-0450(1999)038<0501:ANPRAI > 2.0.CO;2.

Muller, C. J., L. E. Back, P. A. O'Gorman, and K. A. Emanuel, 2009: A model for the relationship between tropical precipitation and column water vapor. Geophys. Res. Lett., 36, L16804, https://doi.org/10.1029/2009GL039667.

Neelin, J. D., O. Peters, J. W.-B. Lin, K. Hales, and C. E. Holloway, 2008: Rethinking convective quasi-equilibrium: Observational constraints for stochastic convective schemes in climate models. Philos. Trans. Roy. Soc. London, 366A, 2579-2602, https://doi.org/10.1098/rsta.2008.0056.

, - _ and K. Hales, 2009: The transition to strong convection. J. Atmos. Sci., 66, 2367-2384, https://doi.org/10.1175/2009JAS2962.1.

Parsons, D. B., K. Yoneyama, and J.-L. Redelsperger, 2000: The evolution of the tropical western Pacific atmosphere-ocean system following the arrival of a dry intrusion. Quart. J. Roy. Meteor. Soc., 126, 517-548, https://doi.org/10.1002/qj.49712656307.

Peters, O., and J. D. Neelin, 2006: Critical phenomena in atmospheric precipitation. Nat. Phys., 2, 393-396, https://doi.org/ 10.1038/nphys314.

Prasad, A. K., R. P. Singh, S. S. Singh, and D. I. P. S. Nanda, 2007: GPS and satellite meteorology for understanding monsoon dynamics over the Indian subcontinent. IAHS Publ., 313, 33-39, https://iahs. info/uploads/dms/13965.08-33-39-313-03-Anup-Prasad.pdf.

Radhakrishna, B., F. Fabry, J. J. Braun, and T. Van Hove, 2015: Precipitable water from GPS over the continental United States: Diurnal cycle, intercomparisons with NARR, and link with convective initiation. J. Climate, 28, 2584-2599, https:// doi.org/10.1175/JCLI-D-14-00366.1.

Rajeevan, M., C. K. Unnikrishnan, J. Bhate, K. N. Kumar, and P. P. Sreekala, 2012: Northeast monsoon over India: Variability and prediction. Meteor. Appl, 19, 226-236, https:/doi.org/10.1002/met.1322.
Redelsperger, J.-L., D. B. Parsons, and F. Guichard, 2002: Recovery processes and factors limiting cloud-top height following the arrival of a dry intrusion observed during TOGA COARE. J. Atmos. Sci., 59, 2438-2457, https://doi.org/10.1175/ 1520-0469(2002)059<2438:RPAFLC $>2.0$.CO;2.

Ridout, J., 2002: Sensitivity of tropical Pacific convection to dry layers at mid- to upper levels: Simulation and parameterization tests. J. Atmos. Sci., 59, 3362-3381, https://doi.org/10.1175/ 1520-0469(2002)059<3362:SOTPCT $>2.0$.CO;2.

Romatschke, U., and R. A. Houze Jr., 2011: Characteristics of precipitating convective systems in the South Asian monsoon. J. Hydrometeor., 12, 3-26, https://doi.org/10.1175/2010JHM1289.1.

Saikranthi, K., 2014: Characteristics of rainfall over India as seen by tropical rainfall measuring mission (TRMM) precipitation radar. Ph.D. thesis, Dept. of Physics, Sri Venkateswara University, 66 pp. , T. N. Rao, M. Rajeevan, and S. V. B. Rao, 2013: Identification and validation of homogeneous rainfall zones in India using correlation analysis. J. Hydrometeor., 14, 304-317, https:// doi.org/10.1175/JHM-D-12-071.1.

,,-- B. Radhakrishna, and S. V. B. Rao, 2014: Morphology of the vertical structure of precipitation over India and adjoining oceans based on long-term measurements of TRMM PR. J. Geophys. Res. Atmos., 119, 8433-8449, https://doi.org/ 10.1002/2014JD021774.

_- B. Radhakrishna, S. K. Satheesh, and T. N. Rao, 2018: Spatial variation of different rain systems during El Niño and La Niña periods over India and adjoining ocean. Climate Dyn., 50, 3671-3685, https://doi.org/10.1007/s00382-017-3833-4.

Satyanarayana, P., and V. V. Srinivas, 2008: Regional frequency analysis of precipitation using large-scale atmospheric variables. $J$. Geophys. Res., 113, D24110, https://doi.org/10.1029/2008JD010412.

Schiro, K. A., J. D. Neelin, D. K. Adams, and B. R. Linter, 2016: Deep convection and column water vapor over tropical land versus tropical Ocean: A comparison between the Amazon and the tropical western Pacific. J. Atmos. Sci., 73, 4043-4063, https://doi.org/10.1175/JAS-D-16-0119.1.

Schumacher, C., and R. A. Houze, 2003: Stratiform rain in the tropics as seen by the TRMM precipitation radar. J. Climate, 16, 1739-1756, https://doi.org/10.1175/1520-0442(2003)016<1739:SRITTA > 2.0.CO;2.

Sherwood, S. C., and R. Wahrlich, 1999: Observed evolution of tropical deep convective events and their environment. Mon. Wea. Rev., 127, 1777-1795, https://doi.org/10.1175/1520-0493(1999) 127<1777:OEOTDC $>2.0 . C O ; 2$.

Singh, R. P., N. C. Mishra, A. Verma, and J. Ramprasad, 2000: Total precipitable water vapor over Arabian and Bay of Bengal using SSM/I data. Int. J. Remote Sens., 21, 2497-2503, https://doi.org/10.1080/01431160050030583.

— S. Dey, A. K. Sahoo, and M. Kafatos, 2004: Retrieval of water vapor using SSM/I and its relation with the onset of the monsoon. Ann. Geophys., 22, 3079-3083, https://doi.org/10.5194/angeo-22-3079-2004.

Sobel, A. H., S. E. Yuter, C. S. Bretherton, and G. N. Kiladis, 2004: Large-scale meteorology and deep convection during TRMM KWAJEX. Mon. Wea. Rev., 132, 422-444, https://doi.org/ 10.1175/1520-0493(2004)132<0422:LMADCD>2.0.CO;2.

Sunilkumar, K., T. N. Rao, and S. Satheeshkumar, 2016: Assessment of small-scale variability of rainfall and multi-satellite precipitation estimates using measurements from a dense rain gauge network in Southeast India. Hydrol. Earth Syst. Sci., 20, 1719-1735, https://doi.org/10.5194/hess-20-1719-2016.

Tompkins, A. M., 2001: Organization of tropical convection in low vertical wind shears: The role of water vapor. J. Atmos. Sci., 58, 529-545, https://doi.org/10.1175/1520-0469(2001)058<0529: OOTCIL $>2.0 . \mathrm{CO} ; 2$ 